\title{
Sciendo
}

\section{Information Technology Reliability in Shaping Organizational Innovativeness of SMEs}

\author{
Katarzyna TWOREK, Katarzyna WALECKA-JANKOWSKA, \\ Anna ZGRZYWA-ZIEMAK
}

Wrocław University of Science and Technology, Faculty of Computer Science and Management, wyb. Wyspianskiego 27, 50-370 Wroclaw, Corresponding author: katarzyna.tworek@pwr.edu.pl

Background and Purpose: This article refers to the relation between information technology (IT) reliability and types of innovations. The main objective of the article is to identify the role of reliability of IT (mainly information reliability) in shaping organization ability to develop different types of innovations, according to Oslo Manual.

Design/Methodology/Approach: Theoretical concept of IT reliability is proposed as a one of innovation determinants. Authors proposed four hypotheses and developed a questionnaire to measure the relation between four types of innovation (product, process, organizational and marketing) and IT reliability. The hypotheses were verified using data collected in 2017 from 400 SMEs operating in Poland.

Results: Information reliability as the whole notion is statistically significantly correlated with all four types of innovation in organization. Searchability, accuracy and relevance of information have significant relation with product, process, organizational and marketing innovation.

Conclusion: The performed empirical research should be treated as the first step of the analysis of innovation determinants, however allowing to draw a set of conclusions useful for the development of next steps of the study.

Keywords: management, information technology, IT reliability, types of innovation

\section{Introduction}

Nowadays organizations operate in dynamic, turbulent, uncertain and competitive environment. That is the reason why organizations are trying to achieve competitive advantage in order to obtain stable market position. There is widespread agreement among authors, researchers, consultants and thinkers in the field of management that innovation is the central capability for all organisations interested in maximizing the opportunities for success in the 21st century (Pereira \& Fernandes, 2018). As Dobni (2010) noticed, innovation is a crucial aspect of survival, growth and profitability of the organization, support- ing the achievement and maintenance of competitive advantage. In order to increase the level of innovative ideas implementation, it is necessary to understand innovation process. Moreover, there are different types of innovation. Therefore, there are different ways in which organizations can be innovative. Practitioners and theoreticians concentrate on the problems of managing innovations, seeking its determinants, which can emerge by minimising barriers to the creation and implementation of different types of innovations. Therefore, it is crucial to identify innovation determinants, considering the typology of innovation. One of the known determinants of organizational innovation is information technology (IT) (Tworek et al. 2018, Corso \& Paolucci 2001; Dewett \& Jones 2001; Xu et al. 2005). In

Received: September 14, 2018; revised: April 10, 2019; accepted: May 15, 2019 
case of innovation, the importance of IT for current business practices has drawn the attention of practitioners and academicians for a long time. As Liao (2003) noticed, the rapid access to information is an important aspect of IT influence on innovation level and a critical factor of success for many organizations enabling innovations. Significance of IT is caused by their ability to support acquisition, locating, transfer and codification of knowledge. However, there are some limitation of IT use in organization. First of all, IT is oriented to the management of well-structured, numerical data, intended for many recipients (Davenport \& Prusak, 1998, Zaliwski, 2000). It does not always allow to show a context and all the links between information. The IT supports the process of knowledge combination, knowledge sharing and enables many users to participate in such activities (Nonaka et al., 2001). In most cases, IT does not offer the possibility to create knowledge, which is developed in the minds of individuals and as a result of interaction between them (Davenport \& Prusak, 1998; Zaliwski, 2000; Nonaka et al., 2001). However, the role of IT in shaping innovative process is also related to communication support. Nonaka with the team (2001) indicate that the importance of using IT should be acknowledged while supporting the constant creation of knowledge, but it must be more deliberately directed towards hidden knowledge. It is necessary to integrate the human and technological subsystem to achieve such an objective. "It is important to perceive technology as potentially supporting human effort, not replacing it" (Sage \& Rouse, 1999, p. 210).

Authors of this article focus on reliability of IT in organization (based on the model developed by Tworek (2019), as a new approach to the analysis of IT in organization, which can be helpful in explaining how IT influences the level of innovation, considering its different types). One of the elements building IT reliability - the reliability of processed information - seems to be especially important determinant of innovation level. Therefore, the main aim of this article is to analyse the relation between the IT reliability (mainly information reliability) and innovation level of the organization.

\section{IT reliability}

Many authors underline that it has become necessary for the organizations to integrate IT into all organizational functions in order to build its potential to influence organizational performance and competitiveness (Tsubira \& Mulira, 2004; Bieńkowska et al., 2017). However, since the relevance and the need for IT use in organization finally seems to be undisputable, there is a need for the analysis and evaluation of its use in organization. The concept of 3 R (reliability, resilience and robustness) (Little, 2003) underlines that the key factor influencing the ability to profit from using IT is its appropriate functioning in organization. Hence, the main element of this concept is IT reliabil- ity. When almost every organization operates using some kind of information system (IS), its reliability seems to be one of the key factors influencing organization's competitive advantage from using it and its ability to benefit from IT during the entire innovation process (Tworek, 2019).

The reliability of IT in organization is understood as measurable property of IT, useful for its control and management, identifying its quality level and pointing out potential problems (Zahedi, 1987) and it is directly linked to the efficiency of IT components, especially those critical to its proper operations (Tworek, 2019). Therefore, it can be said that IT reliability in organization is a notion build by factors connected to three different IT theories. First one is DeLone and McLean success model (DeLone \& McLean, 2003), second one is Lyytinen (1987) four types of IT failure and third one is TAM model (Davis, 1985). Model of IT reliability in organization has been developed by Tworek (2019) and it is presented on Figure 1. The reliability of IT in organization consists of four factors: reliability of information included in IT in organization, reliability of support services offered for IS in the organization and reliability of system itself, which also includes the usability of this system. Each factor is built by series of items, listed on Figure 1 (dark shade indicates the most significant item for the component, than lighter tones indicate lesser importance).

\subsection{Information reliability}

Information reliability - one of four components included in the IT reliability model - is the main topic of this article. That is because it is a well-known fact that information management is conducive for developing innovations (Trantopoulos et al., 2017) and it may by assumed that reliability of those information has an especially important role in this relation. The Conceptual Framework of information reliability was proposed by Financial Accounting Standards Board (FASB) in 1978 and its basic assumptions are still true. The report proposes two characteristics of information reliability. First one is connected to representational faithfulness understood as "the correspondence or agreement between a measure or description and the phenomenon it purports to represent" (FASB 1980, 1163) and it is the most important aspect considering the notion of IT information reliability. Second one is connected to verifiability, understood as "the ability through consensus among measurers to ensure that information represents what it purports to represent or that the chosen method of measurement has been used without error or bias" (FASB 1980, 1163), which is however less important in the context of reliability of information included in IT operating in organization. Moreover, FASB underlined that information reliability is not a binary concept (information is or is not reliable) but rather it should be treated as linear concept with a level of information reliability as a characteristic (FASB 1980, 1159). It is consistent with the findings of 


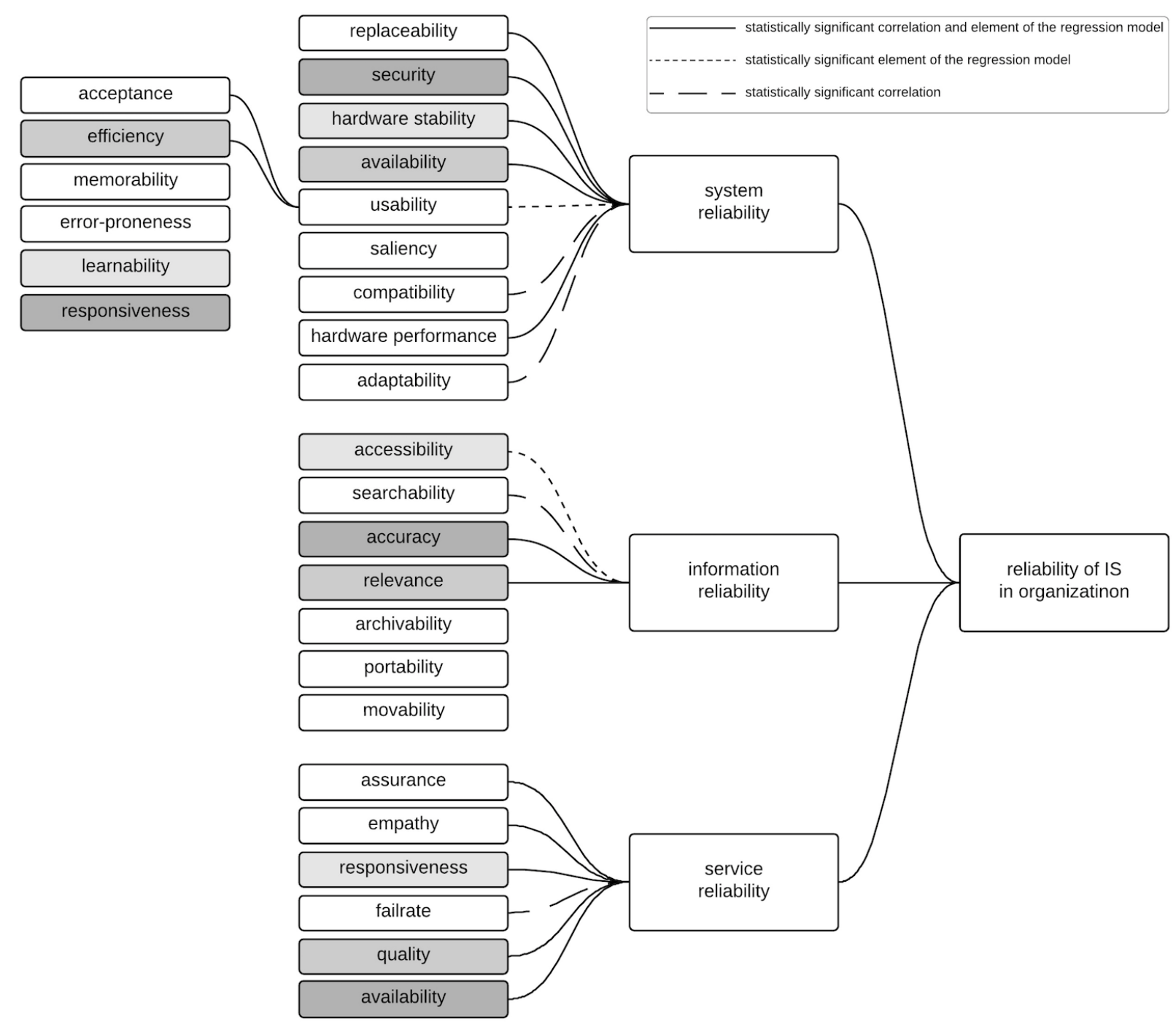

Fig. 1: Model of reliability of IT in organization Source: (Tworek, 2018)

Tworek (2019) formulated as one of the steps of IT reliability model development.

Many authors also recognize that information reliability is closely connected with information quality and credibility - all features that are especially important during processing any information within the organization (Hilligoss \& Rieh, 2008; Kim, 2010; Tomaél, 2000). Moreover, Hilligoss \& Rieh (2008) and Mai (2013) are underlining that information reliability is highly dependable on user evaluation and the information can be considered as reliable or nonreliable only in the context.

All above mentioned arguments can be a basis for the conclusion, that information reliability should be measured with a series of items connected to all aspects of the notion. Hence, based on the literature review and several sets of items (Niu et al, 2013; Palmius, 2007; Finne, 2005; Irani, 2002), Tworek (2019) identified seven items building the notion of information reliability in IT used in organization. Those items are:

- Accessibility, understood as the ability of access information included in IT,

- Searchability, understood as the ability and efficiency of searching through the information included in IT,

- Accuracy, understood as the quality and credibility of information included in IT,

- Relevance, understood as the ability to avoid irrelevant and overlapping information included in IT,

- Archivability, understood as the ease of archive the information included in IT,

- Portability, understood as the ability to move infor- 
mation included in IT between different system environments,

- Movability, understood as the ability to move information included in IT between disk spaces.

\section{Innovation level}

Depending on the discipline, in which term innovation originated (in organisation theory, economics, sociology, technology), the various approaches to it are underlined. Most authors emphasise the organisation's search for new solutions in response to changes in the environment (both changes in customer needs and changes in organisational environment elements such as e.g. technology) (Tidd \& Bessant, 2018). Commonly, innovation is interpreted as the introduction of a new product and is associated with the production process, especially manufacturing technology. As Davila and the team noticed, more rarely is it related to organisational, administrative and cultural changes (Davila et. al. 2006). However, innovation novelty should be understood objectively (the macroeconomic view: innovation is something absolutely new, pioneering work) and subjectively (the microeconomic view: innovation is something new to the organisation, developed and implemented regardless of whether such a solution exists in other organisations). Innovation implies success as a result of implementation of a novelty (it is not just theoretical assumptions or a new idea). Innovative activity should be reflected in improving the use of resources or generating socio-economic benefits like economic profit, personal development of employees, higher job satisfaction, better communication within the organization, the increase of resources knowledge and experience (Walecka-Jankowska 2015).

Schumpeter (1985) described the following types of innovation: new product, method of production, source of supply, method of business organization and the exploitation of new markets. Drucker (2014) distinguished different types of innovation and defined innovation as the process of equipping in new, improved capabilities or increased utility. Nowadays the distinction described in the Oslo methodology is often used (Oslo Manual 2005). This document is the primary international basis of guidelines for defining four types of innovation: process, product, marketing and organizational. In this paper, those four types of innovation are considered in relation with IT reliability - product, process, organizational, marketing. Innovation is connected to new ideas and new knowledge. Development of new knowledge requires information from extrapolation and experimentation, although as Zgrzywa-Ziemak (2015) noticed - the essence of exploration is experimentation with new alternative proposals and the results are uncertain, postponed, often negative and not so unambiguously related to a specific activity. The relation between IT and innovation can be especially seen, while concentrating on different stages of innovation process, because it enables communication between employees and influences the information flow within the organization. Moreover it is one of the key factors supporting information security (Tworek, 2019; Safa et al., 2016). IT enhances sharing of data, information and knowledge by lowering temporal and spatial barriers between employees (Tworek, 2018). At the same time, IT improves access to information and to shared knowledge, which is essential to make new solutions. It can be assumed that on every level of organizational hierarchy, it is necessary to develop knowledge, locate an existing one, diffuse knowledge to all employees, and access up-to-date information that allows decision making. Tasks connected with information reliability, secures the ability of IT to support all those tasks (Tworek et. al 2018, Tworek, 2019; Safa et al., 2016).

\subsection{Product innovation}

Product innovation is understood as the implementation/ commercialization of product or service with improved performance characteristics that delivers objectively new or improved services to the user (Oslo Manual, 2005). Product and/or service innovation entails activities such as design, research and development, acquisition of patents, technology licenses, trademarks, and industrial engineering. From the 1970s, authors emphasized that technology plays an important role in the stimulation of product/ service innovation (Utterback and Abernathy, 1975; Tushman and Anderson, 1986). IT can support especially receiving signals from environment about the possibilities of change and it is crucial for making decision e.g. concerning the domain in which organization is going to compete. Therefore, a broad and extensive mechanism is needed to identify, process and select information from the dynamic environment. Reliability of information included in IT is a prerequisite for supporting those mechanisms. Availability of secure, relevant and up-to-date information is a deal-breaker in case of product innovation (Rehm et al., 2016). Moreover, more advanced innovations might draw from scientific knowledge, generated in universities and research organizations. Such knowledge is often exchanged in personal interactions at a local or regional level (Tödtling et al., 2009; Soto-Acosta et al., 2018). It is important to enable free and secure communication in many different directions. Reliable IT, securing those information flows, influences the ability to generate innovations. Based on that analysis, the following hypothesis can be formulated: H1: The more reliable the IT information in organization, the greater the level of product innovation. 


\subsection{Process innovation}

Process innovation is understood as the implementation of new solution or significant improvement in production or delivery methods (Oslo Manual, 2005). It may involve investment in new technology process, new technology embodied in devices, machinery, tools and equipment, new software for supply-chain management, new business software for designing products and training of staff to offer new services. Organizations, especially manufacturing ones, often improve product quality in product innovation, and in the same time implement cost reduction based on process innovation (Trantopoulos et al., 2017). It can be achieved by decrease of the cost of production and delivery (also by the reduction of time) or by increase of quality. As in the product/service innovation case - IT plays an important role in the stimulation of process innovation. First of all, it can be useful in process of acquisition of knowledge during the phase of seeking new solutions. Second of all, it is crucial for the proper process changes implementation, considering that nowadays IT supports most processes in organization (Janampa et al., 2018). Moreover, IT is essential in process of transfer of new knowledge, especially on the first stage of this process, when organization is choosing from numerous technological and market opportunities (Tidd \& Bessant, 2018). Hence, the following hypothesis can be formulated: H2: The more reliable the IT information in organization, the greater the level of process innovation.

\subsection{Organizational innovation}

An organizational innovation is understood as the implementation of a new solution and significantly improved method in the business practices, management methods, workplace organization or external relations (Oslo Manual, 2005). Organizational innovation is increasing organizational outcomes by gaining access to non-tradable assets (such as non-codified external knowledge) or reducing costs of supplies (Oslo Manual, 2005).

One of the examples of organizational innovation may be the introduction of practices for codifying knowledge by establishing databases of best practices, lessons learnt and other knowledge, so that it can be easily accessible to organization members (Gunday et al., 2011). Organizations need to raise their absorptive capacities to acquire, assimilate, transform, and exploit knowledge which can lead to the organizational innovations (Daghfous, 2004). As Gunday et al. (2011) claim - organizational innovations are strongly related to all the administrative efforts of renewing the organizational routines, procedures, mechanisms, systems, etc. to promote teamwork, information sharing, coordination, collaboration, learning and innovativeness. Therefore, it is necessary to develop knowledge at every level of organization, locate an existing one, diffuse knowledge to all employees, and access up-to-date information that allows decision making (Trantopoulos et al., 2017). All those tasks, needed to obtain organizational innovation, are nowadays impossible to be efficiently implemented without reliable IT. Moreover, absorptive capacity appears to be one of the most important determinants of the organization's ability to acquire, assimilate, and profitably utilize new knowledge to increase its innovation performance (Chen et.al 2009). Features such as accessibility and searchability are needed in order to efficiently process needed information and allow organization members to efficiently use all the information already gathered as the organizational know-how. True value for organizational innovations is generated by the increase in the level of knowledge and the possibility of learning from one's own mistakes, which is impossible without efficient access to information and proper communication flows. Moreover, insufficient transfer of knowledge causes the organization members to reinvent the wheel and is counterproductive in generating organizational innovation (Tidd \& Bessant, 2018). Based on that, the following hypothesis arise: $H 3$ : The more reliable the IT information in organization, the greater the level of organizational innovation.

\subsection{Marketing innovation}

A marketing innovation is understood as the implementation of a new marketing method involving significant changes in product design or packaging, product placement, product promotion, pricing or customer segmentation (Oslo Manual, 2005). Marketing innovations concern addressing customer needs better, opening up new markets, or positioning a product on the market with the intention of increasing organization's sales (Gunday et al., 2011). As Kotler and Keller (2012) assumed in P theory - marketing innovations are strongly related to pricing strategies, product package design properties, product placement and promotion activities. Similarly to the process, product or organizational innovation, the process of gathering information is crucial for marketing innovation to occur. From the vast amount of information concerning customers, it is especially important to identify and obtain those connected to the changing needs of clients and transfer them to the R \& D department (Tidd \& Bessant, 2018; Nguyen et al., 2015). Those tasks are supported by IT, and its reliability also plays a role in this case. Archivability of information seems to be important in building and analysing past marketing strategies. Also, securing relevance of information seems to be a prerequisite for analysing customers information. Moreover, accuracy of information causes marketing innovation to be better tailored to the environment. The research shows that the early inclusion of customers in 
the process of creating innovation (not possible nowadays without IT support) leads to better adoption by the market, better quality of innovation, allows more effective simulation of behaviours, and thus more effective adaptation of the organization's activities (Tidd \& Bessant, 2018). Therefore, the following hypothesis can be formulated: H4: The more reliable the IT information in organization, the greater the level of marketing innovation.

\section{Empirical research methodology}

The survey based on developed questionnaire was conducted in order to identify the relation between the level of IT reliability in organization and innovativeness. The pilot survey was conducted in 2017 among the group of 100 organizations, indicating the issues concerning ambiguity of several questions. Some questions were rewritten based on the obtained feedback. The main survey was conducted later in 2017, among small and medium enterprises (SMEs) located in Poland (organizations employing less than 50 people), using online survey service: SurveyMonkey. The

Table 2: Items building types of innovations

\begin{tabular}{|c|c|}
\hline & Please mark $X$ for actions that have been implemented by your organization last ye \\
\hline \multirow[t]{4}{*}{ process } & 1. New technological processes, crucial for the company's business \\
\hline & $\begin{array}{l}\text { 2. New machines / devices / equipment/ tools, crucial from the business point of view } \\
\text { (excluding standard personal computers) }\end{array}$ \\
\hline & 3. new business-critical software used in the enterprise (only key software) \\
\hline & 4. new business-critical way of services creation \\
\hline product & 5. new business-critical product or service implemented on market \\
\hline \multirow[t]{4}{*}{ marketing } & 6. new business-critical change of implemented product appearance \\
\hline & 7. new business-critical change in the positioning of products or services \\
\hline & 8. new business-critical change in price policy \\
\hline & 9. new business-critical change in customer segmentation \\
\hline \multirow[t]{6}{*}{ organizational } & $\begin{array}{l}\text { 10. new business-critical methods of personal development of employees (career plan- } \\
\text { ning, system of professional qualifications, etc.) }\end{array}$ \\
\hline & $\begin{array}{l}\text { 11. new business-critical methods of business organization i.e. quality management } \\
\text { system }\end{array}$ \\
\hline & $\begin{array}{l}\text { 12. new business-critical methods of delegation of responsibilities and decision-making } \\
\text { by employees }\end{array}$ \\
\hline & 13. new business-critical systemic knowledge management solutions \\
\hline & $\begin{array}{l}\text { 14. new business-critical ways of selling goods or services (including new distribution } \\
\text { channels) }\end{array}$ \\
\hline & 15. new organization of external relations - i.e. outsourcing \\
\hline
\end{tabular}

research was anonymous. Efforts had been made to make sure that the questionnaire was filled in by employees who have a broad view of the entire organization (higher level managers or CEO). A total of 400 valid responses were collected. Since the responses were collected using properly prepared form, the online system counted only those fully and correctly filled in.

Respondents were asked to evaluate innovation level based on 16 questions, which are presented in Table 2. Four types of innovations were evaluated, according to the Oslo Manual (2005).
Respondents were asked to evaluate the IT in the organization based on the list of factors using the five point Likert scale (from very poor to very good with the middle point: fair) - see Table 3. They were asked for the general opinion concerning reliability of system, usage, information and service, and then they were asked to evaluate each factor constructing those 4 variables (see Table 3 ). 
Table 3: Items building reliability of IT

\begin{tabular}{|l|l|l|l|}
\hline Variable: & Variable: & Variable: & Variable: \\
system reliability & usage reliability & information reliability & service reliability \\
\hline$\bullet \quad$ usability & $\bullet$ learnability & $\bullet$ accessibility & $\bullet$ assurance \\
$\bullet \quad$ security & $\bullet$ memorability & $\bullet$ searchability & $\bullet$ empathy \\
$\bullet \quad$ hardware stability & $\bullet$ efficiency & $\bullet$ accuracy & $\bullet$ responsiveness \\
$\bullet \quad$ replicability & $\bullet$ errorproness & $\bullet$ relevance & $\bullet$ quality \\
$\bullet$ saliency & $\bullet$ acceptance & $\bullet$ portability & \\
$\bullet$ compatibility & $\bullet$ responsiveness & & \\
$\bullet \quad$ adaptability & & & \\
\end{tabular}

Using a Likert scale to measure IT reliability seems to be an appropriate choice. First of all, reliability of IT in organization is a subjective notion. Employees own perspective and opinion concerning aspects of IT reliability is the best source of knowledge, since their perception matters the most, that is because IT influences the organization mainly through its potential to influence every-day work of the employees. Quantitative methods are commonly used to assess the software and hardware features linked to the reliability. However, they do not give the information concerning the actual perception of IT reliability within the organization.

Table 4. Descriptive statistics. Source: own work

\begin{tabular}{lccccc}
\hline & Average & Median & Minimum & Maximum & Std. deviation \\
Information reliability & 3,65 & 4 & 1,00 & 5,00 & 1,08 \\
accesibility & 3,67 & 4 & 1,00 & 5,00 & 1,26 \\
searchability & 3,63 & 4 & 1,00 & 5,00 & 1,23 \\
accuracy & 3,82 & 4 & 1,00 & 5,00 & 0,97 \\
relevance & 3,85 & 4 & 1,00 & 5,00 & 1,26 \\
archivability & 3,67 & 4 & 1,00 & 5,00 & 1,15 \\
portability & 3,71 & 4 & 1,00 & 5,00 & 1,23 \\
movability & 3,67 & 4 & 1,00 & 5,00 & 1,41 \\
\hline Product innovation level & 0,74 & 0,85 & 0,00 & 1,00 & 0,27 \\
\hline Process innovation level & 0,77 & 0,75 & 0,00 & 1,00 & 0,29 \\
\hline Organizational innovation level & 0,68 & 0,69 & 0,00 & 1,00 & 0,32 \\
\hline Marketing innovation level & 0,68 & 0,78 & 0,00 & 1,00 & 0,25 \\
\hline
\end{tabular}




\section{Research results}

There were two main variables: information reliability and innovation level calculated for each types of innovations. It is worth noting that Cronbach's $\alpha$ was above 0,890 in case of IT information reliability and even higher for each type of innovation level (every variable), which indicates a high internal reliability of the scales and measurements. Values describing innovation level are calculated based on average values of responses (positive response was as- signed as 1 and negative response as 0 ) to statements in Table 2. Descriptive statistics were calculated for all measured variables (Table 4). Average value of responses given by respondents is followed by median of those responses, its minimal and maximum value and standard deviation.

The r-Pearson correlation coefficients between the information reliability together with all items building this notion and innovation level for each type of innovation have been calculated (Table 5). The results show that IT information reliability is significantly correlated with all types of innovations. However, the correlation is smallest

Table 5. Correlation analysis between IT information reliability and different types of innovation level. Source: own work

\begin{tabular}{|l|l|l|l|l|}
\hline & $\begin{array}{l}\text { Product inno- } \\
\text { vation }\end{array}$ & $\begin{array}{l}\text { Process inno- } \\
\text { vation }\end{array}$ & $\begin{array}{l}\text { Organization- } \\
\text { al innovation }\end{array}$ & $\begin{array}{l}\text { Marketing } \\
\text { innovation }\end{array}$ \\
\hline $\begin{array}{l}\text { IT information relia- } \\
\text { bility }\end{array}$ & $0,432^{* *}$ & $0,298^{* *}$ & $0,562^{* *}$ & $0,523^{* *}$ \\
\hline accesibility & 0,066 & 0,092 & $0,131^{* *}$ & 0,098 \\
\hline searchability & $0,388^{* *}$ & $0,295^{* *}$ & $0,516^{* *}$ & $0,464^{* *}$ \\
\hline accuracy & $0,421^{* *}$ & $0,324^{* *}$ & $0,638^{* *}$ & $0,541^{* *}$ \\
\hline relevance & $0,465^{* *}$ & $0,368^{* *}$ & $0,460^{* *}$ & $0,496^{* *}$ \\
\hline archivability & $-0,001$ & 0,001 & 0,027 & 0,007 \\
\hline portability & 0,054 & 0,045 & 0,086 & 0,073 \\
\hline movability & 0,008 & 0,022 & 0,041 & 0,017 \\
\hline & & & &
\end{tabular}

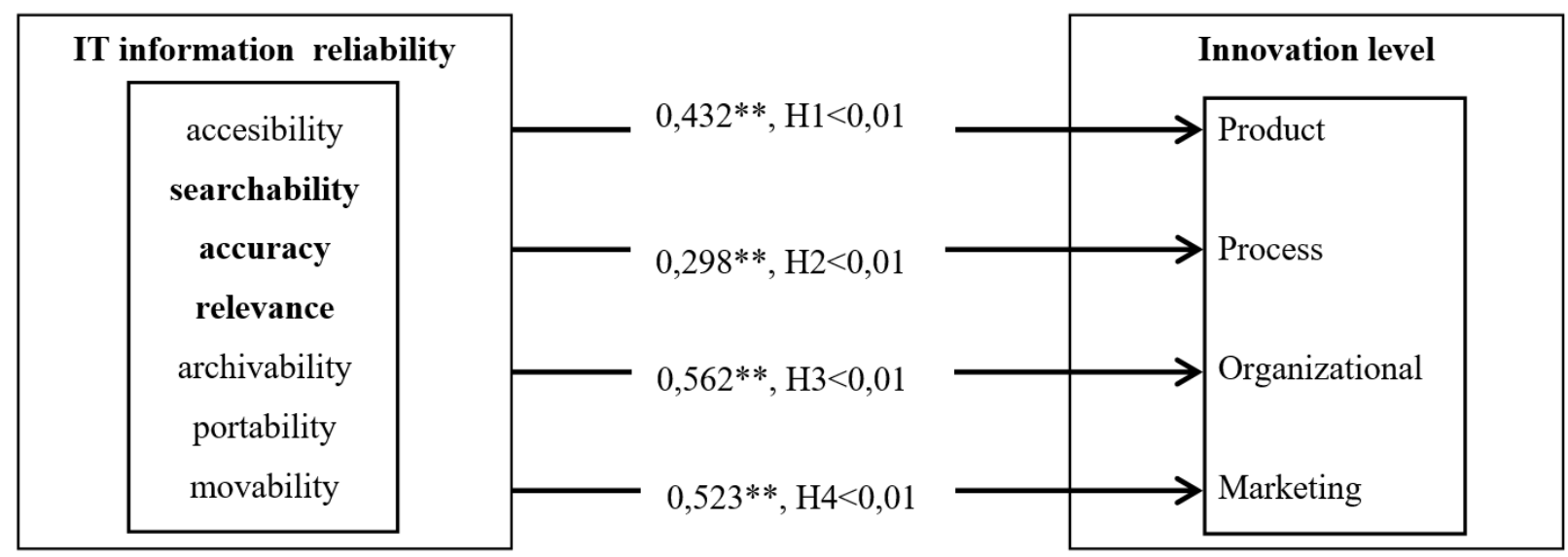

Figure 2: Research hypotheses verification. Source: own work

in case of process innovation and biggest in case of organizational innovation. Moreover, not all individual items are correlated with innovation level in case of every innovation type. Only three of them: searchability, accuracy and relevance proved to be statistically significantly correlated with all types of innovations and the correlation is moderate in all cases. The fourth item - accessibility - is also correlated with organizational innovation, however the correlation coefficient is very low $(r=0,131, p<0,05)$. The highest correlations appear in case of organizational innovation ( $r=0,562, p<0,001$ for IT information reliability as a whole and $\mathrm{r}=0,638, \mathrm{p}<0,001$ for accuracy - the most correlated item) and marketing innovation (however, a little bit lower values). What is surprising, the lowest cor- 
relation appears in case of process innovation $(\mathrm{r}=0,298$, $\mathrm{p}<0,001)$.

As the empirical analysis clearly showed - there is a relation between information reliability and innovation level in case of all four types of innovation. Obtained results are presented in Figure 2.

First of all, based on the r-Pearson correlation analysis it can be concluded that IT information reliability is related to the level of process, product, organizational and marketing innovations in organization. Thus, information reliability as the whole notion is statistically significantly correlated with all types of innovation in organization, which was the basis for accepting hypotheses H1, $\mathrm{H} 2, \mathrm{H} 3$ and $\mathrm{H} 4$. Hence, it positively verifies the views, which arose from the literature review (Trantopoulos et al., 2017), that reliable information included in IT in organization is an important factor building the ability to generate product, process, organizational and marketing innovation. That influence is the biggest in case of organizational and marketing innovation. Hence the information processing needs are definitely the biggest in those two cases, it is not surprising that those correlation were proven to be the highest.

\section{Discussion}

As authors noticed in introduction it is crucial to identify determinants of innovation, considering the typology of innovation. Article concentrates on IT as one of those determinants. The contribution to the existing knowledge in this fields consist of introducing IT reliability as a new method for the evaluation of IT in organization, allowing to focus the considerations on information reliability role in fostering innovation. Therefore the main aim of the article was to empirically verify the relation between information reliability (and its constructs) and the level of innovation in case of four types of innovation. The results show the strongest relation occurring between information reliability and organizational and marketing innovations, then product. The least strong relation occurs between information reliability and process innovation. Moreover, the performed empirical research allowed to conclude that three elements of information reliability are especially important for fostering innovation processes: searchability, accuracy and relevance of information. The analysis revealed that only those 3 out of all items building information reliability are significantly correlated with all types of innovation. It seems to be consistent with the assumptions made based on the literature (Niu et. al., 2013). Searchability of information, understood as the ability and efficiency of searching through the information included in IT, is especially important due to employees' ability to quickly gain access to information which are already available in the organization. That definitely shortens the time of idea creations and influences positively the possibility to gen- erate innovations. Accuracy of information, understood as the quality and credibility of information included in IT, is especially important and can be considered as prerequisite for generating innovations. Basing innovation process on non-accurate information seems to be a potential source of problems for efficient innovation processes. Moreover, relevance of information, understood as the ability to avoid irrelevant and overlapping information included in IT, seems to be important due to the fact that employees gain rapid access to that information, which are crucial and helpful for them in the process of innovation generating. Therefore, it further verifies the views from the literature, that IT gives employees' possibility to communicate, to search for information, to share the knowledge and information reliability is particularly important to make quick decisions based on accurate and up-to-date information (Soto-Acosta, 2018). All of innovations' types need information as a starting point of innovation process, it is a trigger to think of new solutions. IT makes it possible to acquire information from around the world, continuously updating, both through access to knowledge and through the support of free, multidirectional information flow between employees (Trantopoulos et al., 2017).

\section{Conclusions and future research}

The main aim of this article was to analyse the relation between the IT reliability (mainly information reliability) and innovation level of the organization. The obtained results allowed for the conclusion that indeed, there is a significant relation between those notions, which suggests that information reliability is conducive to innovativeness. Moreover, determining the relation between IT, in particular information reliability, and four types innovation, requires the analysis of numerous other factors that are considered to be key to innovation (generally accepted are e.g. corporate culture, knowledge workers, motivation system). Therefore, the performed empirical research should be treated as the first step of the analysis of the broader notion, however allowing to draw a set of conclusions useful for the development of next steps of the study. However, the presented research has some other limitations the hypotheses verification is based on the sample of 400 organizations operating in Poland and further verification in different business contexts is required. Nevertheless, the research presented here can be a solid first step in the process of framework verification. It is a well-known fact that nowadays information is crucial for obtaining ability to generate innovations. Considering the obtained results, it seems logical to assume that it is especially true for process innovations. The performed research caused some new scientific questions to arise: are process innovations even possible without the availability of reliable information? Or will they be misdirected without them? It seems that it is a new direction of research emerging from the 
conclusions obtained in this paper, especially considering the surprisingly lowest correlation obtained for this type of innovation.

\section{Literature}

Abernathy, W. J., \& Utterback, J. M. (1975). Innovation and the evolving structure of the firm. Working Paper HBS-75-18. Boston: Harvard University Press.

Bieńkowska, A., Kral, Z., \& Zabłocka-Kluczka, A. (2017). IT tools used in the strategic controlling process: Polish national study results. In I. Šimberová, A. Kocmanová \& F. Milichovský (Eds.), Perspectives of Business and Entrepreneurship Development in Digital Age: Economics, Management, Finance and System Engineering from the Academic and Practioners Views (pp. 7584). Brno: Brno University of Technology.

Chen, Y. S., Lin, M. J. J., \& Chang, C. H. (2009). The positive effects of relationship learning and absorptive capacity on innovation performance and competitive advantage in industrial markets. Industrial Marketing Management, 38(2), 152-158,

http://doi.org/10.1016/j.indmarman.2008.12.003

Corso, M., \& Paolucci, E. (2001). Fostering innovation and knowledge transfer in product development through information technology. International Journal of Technology Management, 22(1/2/3), 126-148, http://doi.org/10.1504/IJTM.2001.002958

Daghfous, A. (2004). Absorptive capacity and the implementation of knowledge-intensive best practices. S.A.M. Advanced Management Journal, 69(2), 21-27.

Davenport, T.H., \& Prusak, L. (1998). Working Knowledge. How Organizations Manage What They Know, Boston: HBSP.

Davila, T., Epstein, M. J., \& Shelton, R. D. (Eds.). (2006). The creative enterprise: Managing innovative organizations and people, Greenwood Publishing Group.

Davis, F. D. (1985). A technology acceptance model for empirically testing new end-user information systems: theory and results, Doctoral dissertation, Massachusetts Institute of Technology.

Delone, W. H., \& McLean, E. R. (2003), The DeLone and McLean model of information systems success: a tenyear update. Journal of Management Information Systems, 19(4), 9-30, http://doi.org/10.1080/07421222.2003.11045748

Dewett, T., \& Jones, G. R. (2001). The role of information technology in the organization: a review, model and assessment. Journal of Management, 27(3), 313-346, http://doi.org/10.1016/S0149-2063(01)00094-0

Dobni, C. B. (2010). The relationship between an innovation orientation and competitive strategy. International Journal of Innovation Management, 14(02), 331-357, https://doi.org/10.1142/S1363919610002660
Drucker, P. (2014). Innovation and entrepreneurship. Routledge.

Fagerberg, J., Mowery, D.C., \& Nelson R.R. (2004). The Oxford Handbook of Innovation, Oxford: Oxford University Press.

Financial Accounting Standards Board (1978). Statement of Financial Accounting Concepts No. 1, Objectives of Financial Reporting by Business Enterprises. Stanford: FASB.

Gunday, G., Ulusoy, G., Kilic, K., \& Alpkan, L. (2011). Effects of innovation types on firm performance. International Journal of Production Economics, 133(2), 662-676, https://doi.org/10.1016/j.ijpe.2011.05.014

Hilligoss, B., \& Rieh, S.Y. (2008). Developing a unifying framework of credibility assessment: construct, heuristics, and interaction in context. Information Processing \& Management, 44(4), 1467-1484, http://doi.org/10.1016/j.ipm.2007.10.001

Janampa, R., Melendez, K., \& Dávila, A. (2018). Information Technology Service Management Processes for Very Small Organization: A Proposed Model. In J. Mejia et al. (Eds.), Trends and Applications in Software Engineering: Proceedings of the 7th International Conference on Software Process Improvement (CIMPS 2018) (Vol. 865, pp. 55-68). Springer, http://doi.org/10.1007/978-3-030-01171-0 5

Kim, S. (2010). Questioners' credibility judgments of answers in a social question and answer site. Information Research, 15(2), from http://InformationR.net/ir/15-2/paper432.html

Kotler, P., Keller, K. L. (2012). Marketing Management, $14^{\text {th }}$ ed., Global Edition, New Jersy: Prentice Hall.

Lyytinen, K. (1987). Different perspectives on information systems: problems and solutions. ACM Computing Surveys (CSUR), 19(1), 5-46, http://doi.org/10.1145/28865.28867

Mai, J.E. (2013). The quality and qualities of information. Journal of the American Society for Information Science and Technology, 64(4), 675-688, http://doi.org/10.1002/asi.22783

Niu, N., Da Xu, L., \& Bi, Z. (2013). Enterprise information systems architecture - Analysis and evaluation. IEEE Transactions on Industrial Informatics, 9(4), 2147-2154, http://doi.org/10.1109/TII.2013.2238948

Nonaka, I., Toyama, R., \& Byosière, Ph. (2001). The Theory of Organizational Knowledge Creation: Understanding the Dynamic Process of Creating Knowledge. In M. Dierkes, A. B. Antal, J. Child \& I. Nonaka (Eds.), Handbook of Organizational Learning and Knowledge (pp. 491-517), New York: Oxford University Press.

Nguyen, T. H., Newby, M., \& Macaulay, M. J. (2015). Information technology adoption in small business: Confirmation of a proposed framework. Journal of Small Business Management, 53(1), 207-227, http://doi.org/10.1111/jsbm.12058

Oslo Manual (2005). Oslo Manual: Proposed Guidelines 
for Collecting and Interpreting Technological Innovation Data. Paris: OECD. Retrieved from https://www.oecd-ilibrary.org/science-and-technology/oslo-manual 9789264013100-en

Palmius, J. (2007). Criteria for measuring and comparing information systems. In: Proceedings of the 30th Information Systems Research Seminar in Scandinavia IRIS 2007, 11-14.8.2007 (pp. 823-846). Murikka, Tampere, Finland.

Pereira, E. T., \& Fernandes, A. J. (2018). Are the most innovative SMEs the most competitive ones? Theory and Applications in the Knowledge Economy, 77. Conference Theory and Applications in the Knowledge Economy - TAKE 2018, Poznan, July 11-13, 2018.

Rehm, S. V., Goel, L., \& Junglas, I. (2016). Information management for innovation networks - an empirical study on the "who, what and how" in networked innovation. International Journal of Information Management, 36(3), 348-359,

http://doi.org/10.1016/j.ijinfomgt.2015.11.004

Safa, N. S., Von Solms, R., \& Furnell, S. (2016). Information security policy compliance model in organizations. Computers \& Security, 56, 70-82, http://doi.org/10.1016/j.cose.2015.10.006

Sage, A.P., \& Rouse, W.B. (1999). Information Systems Frontiers in Knowledge Management. Information Systems Frontiers, 1(3), 205-219, http://doi.org/10.1023/A:1010046210832

Liao, S.-H., (2003). Knowledge Management technologies and applications - literature review from 1995-2002. Expert Systems with Applications, 25(2), 155-164, http://doi.org/10.1016/S0957-4174(03)00043-5

Soto-Acosta, P., Popa, S., \& Martinez-Conesa, I. (2018). Information technology, knowledge management and environmental dynamism as drivers of innovation ambidexterity: a study in SMEs. Journal of Knowledge Management, 22(4), 824-849, http://doi.org/10.1108/JKM-10-2017-0448

Tidd, J., \& Bessant, J. R. (2018). Managing innovation: integrating technological, market and organizational change. John Wiley \& Sons.

Tödtling, F., Lehner, P., \& Kaufmann, A. (2009). Do different types of innovation rely on specific kinds of knowledge interactions? Technovation, 29(1), 59-71, http://doi.org/10.1016/j.technovation.2008.05.002

Tomaél, M.I. (2000). Fontes de informação na Internet: acesso e avaliação das disponíveis nos sites de universidades, Seminário Nacional de Bibliotecas Universitárias, Florianópolis, Vol. 6.

Tushman, M. L., \& Anderson, P. (1986). Technological discontinuities and organizational environments. Administrative Science Quarterly, 31(3), 439-465, http://doi.org/10.2307/2392832

Tusubira, F., \& Mulira, N. (2004). Integration of ICT in organizations: Challenges and best practice recommendations based on the experience of Makerere Uni- versity and other organizations. In F.F. Tusubira \& N. $\mathrm{K}$. Mulira (Eds.), Universities: taking a leading role in ICT enabled human development (pp. 6-13). Kampala, Uganda: Phanton Solutions.

Trantopoulos, K., von Krogh, G., Wallin, M. W., \& Woerter, M. (2017). External knowledge and information technology: Implications for process innovation performance. MIS Quarterly, 41(1), 287-300, http://doi.org/10.25300/MISQ/2017/41.1.15

Tworek, K. (2018). Reliability of information systems in organization in the context of banking sector: Empirical study from Poland. Cogent Business \& Management, 5(1), 1522752, http://doi.org/10.1080/23311975.2018.1522752

Tworek, K. (2019). Aligning IT with business. Springer, Cham, http://doi.org/10.1007/978-3-030-11563-0

Tworek, K., Walecka-Jankowska, K., \& Zgrzywa-Ziemak, A. (2019). Information Systems Reliability and Organizational Performance. In Information Systems Architecture and Technology: Proceedings of 39th International Conference on Information Systems Architecture and Technology - ISAT 2018 (pp. 201-210). Advances in Intelligent Systems and Computing, Vol. 854. Springer Cham, http://doi.org/10.1007/978-3-319-99993-7_18

Utterback, J.M. (1975). A dynamic model of process and product innovation. Omega, 3(6), 639-656, http://doi.org/10.1016/0305-0483(75)90068-7

Walecka-Jankowska, K. (2015). Relationship between knowledge management and innovation. Social Sciences, 90(4), 55-66, http://doi.org/10.5755/j01.ss.90.4.14260

Xu, H., Sharma, S. K., \& Hackney, R. (2005). Web services innovation research: towards a dual-core model. International Journal of Information Management, 25(4), 321-334, http://doi.org/10.1016/j.ijinfomgt.2005.04.004

Zahedi, F. (1987). Reliability of information systems based on the critical success factors-formulation. MIS Quarterly, 11(2), 187-203, http://doi.org/10.2307/249362

Zaliwski A.: Korporacyjne bazy wiedzy [Corporate knowledge bases], PWE, Warszawa 2000.

Zgrzywa-Ziemak, A. (2015). The impact of organisational learning on organisational performance. Management and Business Administration. Central Europe, 23(4), 98-112, http://doi.org/10.7206/mba.ce.2084-3356.159

Katarzyna Tworek Ph.D. in economic sciences, in the discipline of management science. Works as assistant professor at the Wrocław University of Technology, Faculty of Computer Science and Management, Department of Organization Management and Development. Scientific interests focus on use of information technology in organizations, with the special emphasis on IT reliability. 
Katarzyna Walecka-Jankowska Ph.D. in economic sciences, in the discipline of management science. Works as assistant professor at the Wrocław University of Technology, Faculty of Computer Science and Management, Department of Organization Management and Development. Scientific interests focus on innovation and knowledge management.
Anna Zgrzywa-Ziemak Ph.D. in economic sciences, in the discipline of management science. Works as assistant professor at the Wrocław University of Technology, Faculty of Computer Science and Management, Department of Organization Management and Development Scientific interests focus on business sustainability and organization's learning. 